\title{
PEMBUATAN ALAT PENJEMUR KOPI
}

\section{Wahyudhi Sutrisno ${ }^{1)}$, Nur Amiralmahdi ${ }^{2)}$, Benny Wibowo ${ }^{3)}$}

\author{
Universitas Islam Indonesia \\ Jalan Kaliurang No.Km. 14,5, Besi, Umbulmartani, Kec. Ngemplak, Kabupaten Sleman, Daerah \\ Istimewa Yogyakarta, Indonesia \\ e-mail:wahyudhi.sutrisno@uii.ac.id
}

\begin{abstract}
ABSTRAK
Pengeringan biji kopi di Desa Kemiri dilakukan dengan cara alami yaitu menjemur biji kopi dibawah sinar matahari dengan beralas karung, belum ada para petani kopi yang menggunakan alat untuk mengeringkan kopi. Padahal pengeringan biji kopi menggunakan alat pengering dapat mempercepat proses pengeringan dan menghemat waktu, tanpa terkendala musim hujan dan menghasilkan kualitas yang lebih baik. Pengeringan yang dilakukan dengan alat penjemur kopi dapat membuat biji kopi kering lebih merata dan sempurna. Alat penjemur kopi tersebut menggunakan prinsip seperti jendela nako, yakni dapat berputar $180^{\circ}-360^{\circ}$. Dengan menggunakan alat penjemur kopi dapat mengatur posisi kemiringan wadah sesuai dengan arah datangnya matahari agar biji kopi dapat kering lebih merata.
\end{abstract}

Kata Kunci: Desa Kemiri, Pengeringan, Biji Kopi, Alat Penjemur Kopi

\begin{abstract}
Drying of coffee beans in Kemiri village is done in a natural way that dried coffee beans under the sun with a grounded sack, there are no coffee farmers who use the tool to dry the coffee beans. Although, drying the coffee beans using the dryer tool can accelerate the drying process and save the time, without the rainy season constrained and produce better quality. Drying is done with a coffee drying tool can make the coffee beans dry more evenly and perfectly. The coffee drying tool uses principles such as the Nako window, which can rotate $180^{\circ}-360^{\circ}$. Using a coffee drying tool can adjust the position of the slope of the container in accordance with the direction of the coming sun so that the coffee beans can dry more evenly
\end{abstract}

Keyword: Kemiri Village, Drying, Coffee Beans, The Coffee Drying Tool

\section{Pendahuluan}

Masyarakat Desa Kemiri, Kabupaten Purworejo, Provinsi Jawa Tengah, sebagian besar memiliki mata pencaharian sebagai petani. Salah satu hasil pertanian yang dihasilkan oleh masyarakat Desa Kemiri adalah kopi. Sayangnya proses yang dilakukan oleh para petani kopi di desa kemiri dalam pengelolaan biji kopi masih menggunakan cara-cara yang konvensional. Salah satunya adalah proses penjemuran biji kopi. Penjemuran biji kopi masih dilakukan secara konvensional yaitu dengan cara menghamparkan biji kopi diatas tanah dengan dialasi karung atau terpal. Metode penjemuran biji kopi ini seperti ini tentu saja tentu saja hasilnya kurang maksimal, diantaranya masih ada beberapa biji kopi yang belum kering sempurna dan juga biji kopi menjadi kurang higienis karena mudah terkena kotoran binatang, tanah dan krikil. Selain itu juga, biji kopi akan menghasilkan kopi yang kualitas rasa dan aromanya kurang baik, hal ini dikarenakan biji kopi bersifat higroskopis yaitu kemampuan kopi dalam menyerap kelembapan udara di sekitarnya (https://tanameracoffee.com/ID/aneka-ragam-keunikan-kopi/). Berarti biji kopi jika dijemur berada dalam kondisi yang lembab, maka biji kopi akan menyerap udara yang ada di sekitarnya sehingga rasa kopi akan hilang. Berdasarkan permasalahan tersebut, maka dibutuhkan perancangan alat 
penjemur biji kopi yang membuat penjemuran kopi dapat kering maksimal dan rasa serta aroma kopi tetap terjaga kualitasnya.

\section{Tinjauan Pustaka}

Menurut Rahardjo (2012), biji kopi yang sudah dipetik sebaiknya segera diolah lebih lanjut kurang lebih dari 12 sampai 20 jam agar biji kopi tersebut tidak mengalami fermentasi dan proses kimia lainnya yang bisa menurunkan mutu dari biji kopi tersebut. Proses pengolahan kopi menurut Ciptadi dan Nasution (1985) dibagi menjadi dua proses yaitu proses olah kering dan proses olah basah. Para petani kopi di Indonesia pada umumnya hanya mengenal cara pengolahan kering, hal ini disebabkan prosesnya yang lebih sederhana dan kapasitas olahannya kecil. Prinsip pengolahan ini adalah biji kopi yang sudah dipetik lalu dikeringkan dengan panas matahari sampai buahnya menjadi kering, selama 14 sampai 20 hari. Proses pengeringan merupakan salah satu tahapan penting dalam pengolahan biji kopi (Santoso, 2018). Semakin cepat kering maka mutu kopi semakin baik, karena frementasi cepat berakhir. Proses pengeringan adalah proses penurunan kadar air bahan pertanian sampai batas tertentu sebelum bahan diolah atau dimanfaatkan sehingga diharapkan dapat memperlambat laju kerusakan yang disebabkan oleh aktivitas biologis dan kimia (Broker et al, 1974). Hal ini juga sesuai dengan Hendarson dan Perry (1976), yang menyatakan bahwa pengeringan adalah proses pengeluaran air dari suatu bahan pertanian pada tingkat kadar air dimana mutu bahan pertanian tidak menurun akibat serangan jamur, enzim dan aktifitas serangga.

\section{Metodologi Penelitian}

1) Observasi ke petani kopi Desa Kemiri

Observasi dilakukan dengan cara mewawancarai petani-petani kopi yang ada di Desa Kemiri. Dari observasi diketahui bahwa seluruh proses pengelolaan kopi dilakukan dengan cara konvensional dan menggunakan alat yang sederhana. Proses pengeringan kopi dilakukan dengan cara alami yaitu dengan menjemur kopi menggunakan matahari dimana kopi dihamparkan pada karung atau terpal dan dijemur di tanah yang lapang.

2) Pembuatan desain alat penjemur kopi

Desain alat penjemur kopi dilakukan dengan menggunakan aplikasi Autodesk Inventor 2019. Mekanisme dari model desain alat penjemur kopi mirip dengan mekanisme jendela nako (Louvre Window). Louvre merupakan susunan paralel, bilah horizontal, bilah, reng, slip kaca, kayu, atau bahan lain yang dirancang untuk mengatur aliran udara atau penetrasi cahaya. Mekanisme jendela nako yaitu semua jendela diberi bearing di kedua sisi penempelannya, disambung dengan coupler dalam bentuk batang dengan tuas di tengah komponennya, dan ketika tuas tersebut diputar maka semua jendela akan ikut berputar. Hanya saja, dalam alat ini diganti dengan gear sebagai pengganti coupler-nya agar bisa berputar lebih dari $180^{\circ}$.

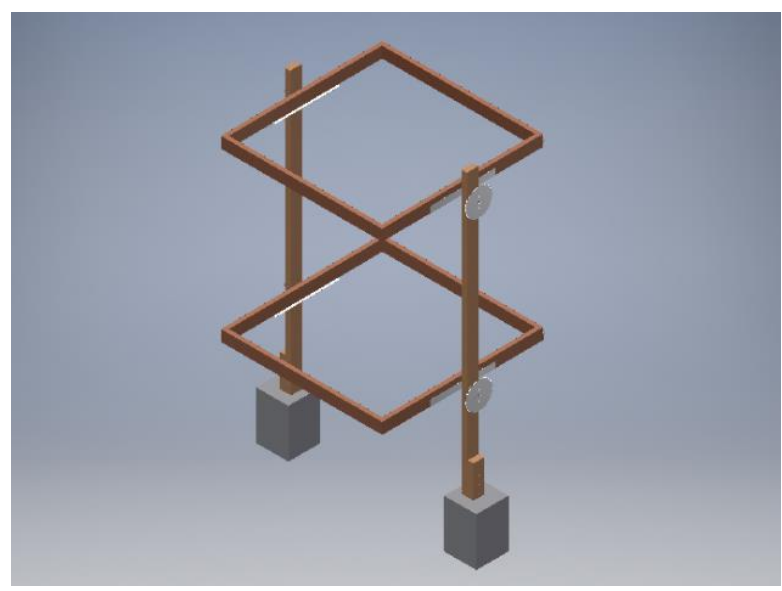

Gambar 1. Desain Alat Penjemur Kopi 
3) Pembuatan komponen-komponen alat penjemur kopi

Dalam tahap pendesainan model dan mekanisme alat, terdapat satu kali revisi desain dikarenakan adanya ketidakmungkinan dalam dunia nyata jika model tersebut direalisasikan. Dalam pembuatan komponen juga terdapat revisi hampir semua model komponen, kecuali model komponen yang beli di toko spare-part motor saja seperti rantai, gear, dan bearing dikarenakan sudah dalam bentuk jadi ketika dibeli. Pembuatan komponen alat penjemur kopi dibagi menjadi dua tempat, yaitu pembuatan komponen dari logam dan pembuatan komponen dari kayu. Sebagian komponen-komponennya dapat dilihat pada gambar 2 berikut ini:

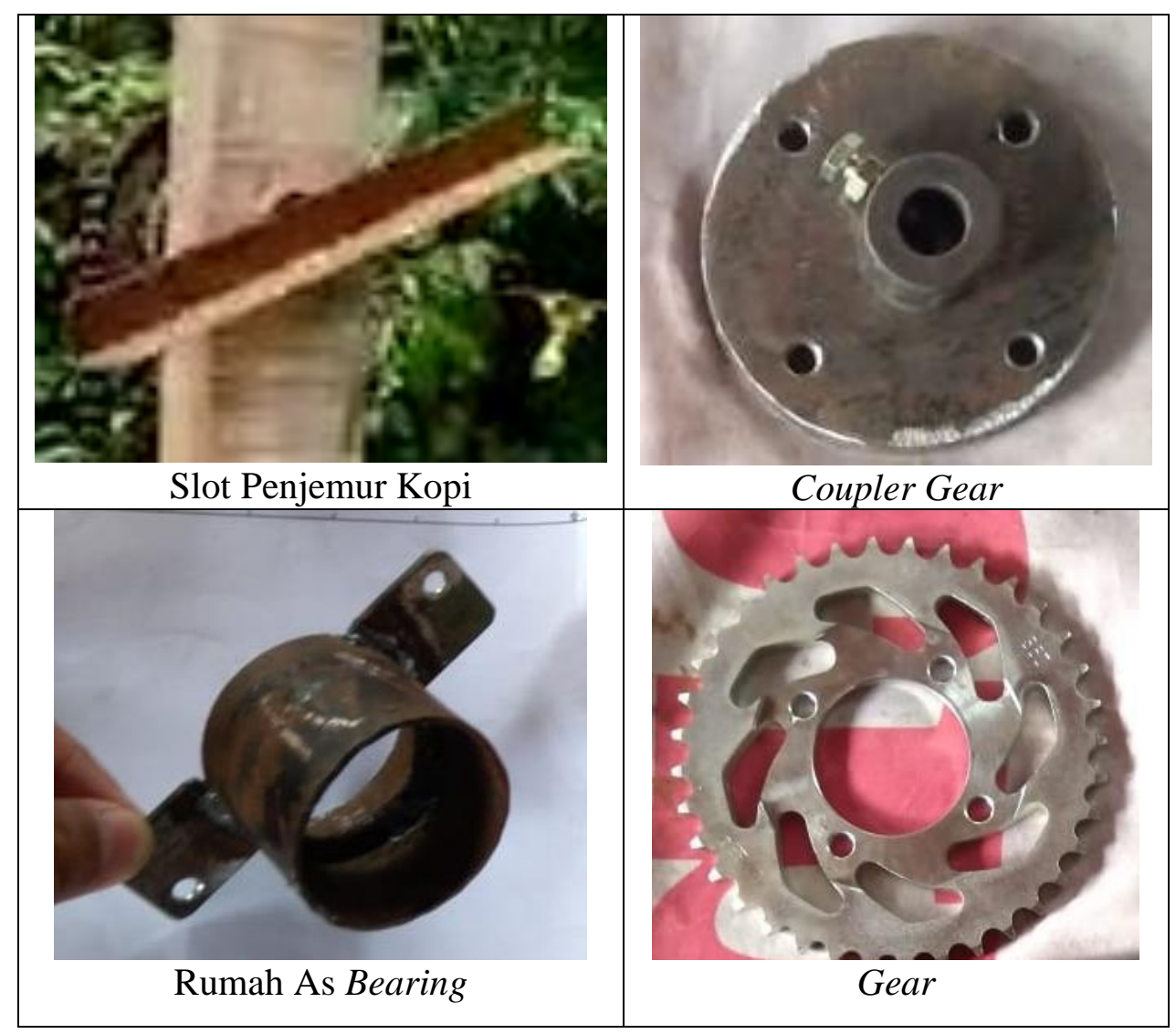

Gambar 2. Komponen-komponen Alat Penjemur Kopi

4) Simulasi pemasangan alat penjemur kopi

Ketika simulasi pemasangan alat penjemur kopi, terjadi tabrakan antara penjemur kopi atas dan penjemur kopi bawah. Hal ini terjadi dikarenakan pengurangan jumlah rantai, sehingga jarak antara gear atas dan gear bawah menjadi berkurang yang menyebabkan terjadinya tabrakan. Solusinya dengan menaikan posisi penjemur kopi bagian atas pada slot penjemur kopi agar bagian bawah penjemur kopi atas tidak terbentur dengan bagian atas penjemur kopi bawah. Konsekuensinya alat penjemur kopi hanya bisa berputar $180^{\circ}$ saja. Simulasi dengan menggunakan biji kopi basah tidak dilaksanakan karena sedang tidak musim panen biji kopi. Sebagai gantinya, simulasi dilakukan menggunakan biji kopi yang sudah kering. Simulasi tersebut dilakukan untuk memastikan kerapatan penjemur kopi. Hasilnya, masih terdapat biji kopi yang jatuh sedikit. Solusinya dengan mengencangkan pengunci penjemur kopi dan merapat kan posisinya.

5) Sosialisasi alat penjemur kopi

Melakukan sosialisasi cara pemasangan alat penjemur kopi dan juga cara menggunakan alat tersebut agar dapat dimanfaatkan secara maksimal oleh masyarakat Desa Kemiri khususnya bagi Petani Kopinya 


\section{Hasil dan Pembahasan}

Perancangan alat penjemur kopi ini belum sampai pada tahap uji coba di lapangan, baru sampai pada tahap simulasi penggunaan kepada masyarakat. Alat dibuat melalui beberapa metode, yaitu observasi kepada petani kopi, mendesain alat yang sesuai, membuat komponen-komponen alat secara nyata, memasang dan simulasi alat penjemur kopi serta sosialisasi alat penjemur kopi kepada Petani Kopi. Alat penjemur kopi ini mempunyai dua prinsip kerja. Prinsip pertama adalah mengeringkan biji kopi melalui cahaya matahari secara maksimal. Hal ini didapatkan dengan cara membolakbalikan biji kopi ketika dijemur, sehingga biji kopi terkena sinar matahari merata secara keseluruhan. Prinsip kedua adalah menjaga kualitas rasa dan aroma kopi. Posisi penjemuran biji kopi yang berada diatas permukaan tanah akan menjaga biji kopi dari menyerap kelembapan udara yang ada disekitarnya.

Kelebihan alat penjemur kopi ini dibandingkan dengan alat penjemur kopi lainnya adalah:

1) Biaya pembuatan yang murah yaitu hanya sekitar Rp 1.300.000., dibandingkan dengan alat penjemur kopi lainnya yang harganya rata-rata diatas Rp 5.000.000., bahkan ada alat pengering kopi yang sampai puluhan juta.

2) Hemat biaya operasional karena menggunakan sinar matahari dan digerakkan secara manual atau tidak menggunakan mesin. Sehingga tidak ada biaya operasional untuk listrik dan juga biaya perawatannya juga murah.

3) Mudah untuk dioperasionalkan. Berdasarkan simulasi dilapangan, masyarakat bisa mengoperasikan alat penjemur kopi secara mandiri, karena tidak memerlukan mekanisme yang rumit untuk mengoperasionalkannya.

Sedangkan kelemahan alat penjemur kopi ini dibandingkan dengan alat penjemur kopi lainnya dalah:

1) Penjemuran sangat tergantung dengan matahari, sehingga jika cuaca mendung atau hujan, maka alat ini tidak bisa dioperasionalkan dengan optimal, bahkan bisa berhenti beroperasional.

2) Kapasitas penjemuran kopi masih terbatas jika dibandingkan dengan alat penjemur kopi lainnya. Berdasarkan simulasi penggunaan kepada masyarakat maka dapat diketahui bahwa alat penjemur kopi ini bisa langsung digunakan masyarakat. Alat penjemur kopi ini juga bisa dikembangkan lebih baik lagi, mulai dari model dan mekanisme alat.

\section{Daftar Pustaka}

Aak. (1980). Budidaya Tanaman Kopi. Yogyakarta: Yayasan Kanisius

Brooker, D. B., F. W. Bakker-arkema and C. W. Hall, (1974). Drying Cereal Grains. Wesport: The AVI publishing Company, Inc.

Ciptadi dan MZ Nasution. (1985). Pengolahan Kopi. Bogor: Agro Industri Press

Danarti dan Najayati, S. (2004). Kopi : Budidaya dan Penanganan Pasca Panen. Jakarta: Penebar Swadaya.

Hendarson, S. M. and R. L. Perry. 1(976). Agricultural Process Engineering. 3 rd ed. The AVI publ. Co., Inc, Wesport, Connecticut, USA

Rahardjo, Pudji. (2012). Panduan Budidaya dan Pengolahan Kopi Arabika dan Robusta. Jakarta: Penebar Swadaya.

Santoso, D. Djunaedi, M. dan Mursalim. (2018). Model Matematis Pengeringan Lapisan Tipis Biji Kopi Arabika (Coffeae Arabica) dan Biji Kopi Robusta (Coffeae cannephora). Jurnal Teknologi Pertanian Andalas Vol. 22, No.1

Tanameracoffee.com/ (2017, 31 Maret). Aneka Ragam Keunikan Kopi. 14 Juni 2020. https://tanameracoffee.com/ID/aneka-ragam-keunikan-kopi/ 